\title{
Hypertension affects the biocompatibility and biomineralization of MTA, High-plasticity MTA, and Biodentine ${ }^{\circledR}$
}

Leopoldo COSME-SILVA(a)

Renan DAL-FABBRO(a)

Luanna de Oliveira GONÇALVES(a)

Alana Sant'Ana do PRADO(a)

Flávia Alfredo PLAZZA ${ }^{(a)}$

Naiana Viana VIOLA(b)

Luciano Tavares Angelo CINTRA(a)

João Eduardo GOMES FILHO(a)

(a) Universidade Estadual Paulista - Unesp, School of Dentistry, Departament of Endodontics, Araçatuba, SP, Brazil.

(b) Universidade Federal de Alfenas - Unifal, School of Dentistry, Departament of Surgery, Alfenas, MG, Brazil.

Declaration of Interests: The authors certify that they have no commercial or associative interest that represents a conflict of interest in connection with the manuscript.

\section{Corresponding Author:}

João Eduardo Gomes Filho

E-mail: joao@foa.unesp.br

hitps://doi.org/10.1590/1807-3107bor-2019.vol33.0060

Submitted: December 19, 2018

Accepted for publication: May 14, 2019

Last revision: June 11, 2019
Abstract: This study evaluated the effect of hypertension on tissue response and biomineralization capacity of white Mineral Trioxide Aggregate (MTA), High-plasticity MTA (MTA HP), and Biodentine ${ }^{\circledast}$ (BDT) in rats. Polyethylene tubes filled with MTA, MTA HP, BDT, and the control group (empty tubes) were placed into the dorsal subcutaneous tissue of 32 male rats (16 normotensive (NT) and 16 hypertensive rats - 8 per group). After 7 and 30 days, the polyethylene tubes surrounded by connective tissue were removed, fixed, and embedded in histological resin. The mean number of inflammatory cells was estimated in HE-stained sections, biomineralization was quantified as area $\left(\mu \mathrm{m}^{2}\right)$ by Kossa (VK) staining, and examination by polarized light (LP) microscopy was performed. The differences amongst the groups were analyzed statistically by the Mann-Whitney or Student's $t$ test, according to Shapiro-Wilk test of normality $(\mathrm{p}<0.05)$. The inflammatory responses to all materials were greater in hypertensive rats than in NT rats $(\mathrm{p}<0.05)$. Positive VK staining in MTA and BDT were more pronounced in NT rats at 7 and 30 days $(p<0.05)$. Birefringent structures in LP for MTA, MTA HP, and BDT were more pronounced in NT rats at 7 days $(p<0.05)$. In rats, hypertension was able to increase inflammatory infiltrate and decrease biomineralization of the tested materials.

Keywords: Endodontics; Materials Testing; Hypertension.

\section{Introduction}

Hypertension (HTN) is a chronic inflammatory disease diagnosed when systolic blood pressure exceeds $140 \mathrm{mmHg}$ and diastolic pressure exceeds $90 \mathrm{mmHg}{ }^{1,2}$ In contemporary society, blood pressure levels increase continuously with age. ${ }^{1,2,3}$ Over the years, people are more exposed to risk factors for HTN such as excessive consumption of sodium, insufficient consumption of potassium, alcohol consumption, sedentary lifestyles, and obesity, as well as genetic predisposition. ${ }^{4,5}$

It is estimated that approximately one in every four adults has HTN. ${ }^{6}$ This population is more prone to cerebrovascular accident, heart failure, myocardial infarction, arterial aneurysm, chronic renal failure, and cognitive impairment. Therefore, HTN is one of the major causes of mortality and incapacitation in the world. ${ }^{1,2,3,6}$ HTN can modify calcium metabolism 
leading to increased bone loss and consequent increase in calcium removal from bones, ${ }^{7}$ it can cause defects in bone healing, increase osteoclast activity, and favor pathologies such as rheumatoid arthritis and apical periodontitis. ${ }^{8,9}$ In addition, HTN is linked to the increase of reactive oxygen species in humans. ${ }^{10}$ The high production of these molecules can lead to increased inflammation through the activation of other molecules with pro-inflammatory activity, such as tumor necrosis factor alpha (TNF $\alpha$ ), which is associated with dysfunction and cell death. ${ }^{10}$ Moreover, high blood pressure can affect circulation and interfere with wound healing, once it reduces blood flow and oxygenation. Thus, HTN can negatively interfere in the process of bone and tissue repair. ${ }^{7}$

As HTN is a disease related to inflammatory disorders, it can interfere with the mineralization process after the use of bioactive endodontic materials. ${ }^{11}$ Mineral Trioxide Aggregate (MTA) (Angelus ${ }^{\circledR}$ Industria de Produtos Odontologicos S/A, Londrina, Brazil), Biodentine $^{\circledR}$ (BDT) (Biodentine; Septodont Inc., SaintMaur-des-Fosses, France), and High-plasticity MTA (MTA HP) (Angelus ${ }^{\circledR}$ ) are calcium, silicate-based repair cements; the latter two are considerably recent materials, which are claimed to have better biological properties, exhibit biocompatibility, and induce tissue mineralization in the region where they are inserted.12,13,14,15 These materials are of clinical importance because they are recommended for pulp exposure, root perforations, and apexification. ${ }^{16,17,18,19}$ As HTN is a disease related to inflammatory disorders and can interfere with the biomineralization process, the aim of the present study was to investigate whether HTN interferes in the tissue response to MTA, MTA HP, and Biodentine ${ }^{\circledast}$ in rat subcutaneous tissues. The null hypothesis is that the tested materials show no differences in inflammatory reaction and in biomineralization capability between hypertensive and normotensive rats.

\section{Methodology}

\section{Animals}

Thirty-two (16 spontaneously hypertensive (SHR) and 16 normotensive (NT)) male Wistar rats aged 3 months were used in this study. Sample size estimates were based on data from a previous study, considering an alpha error of 0.05 and an $80 \%$ power for a significant difference, at least eight animals per group were necessary. They were arranged into four groups: SHR-7, SHR-30, NT-7, and NT-30. The animals were housed in temperature-controlled rooms and received water and food ad libitum. Animal care was provided according to the Research Ethics Committee of Araçatuba School of Dentistry-UNESP, which approved the study protocol before the beginning of the experiments (FOA no. 00451-2017).

\section{Surgical procedures}

Polyethylene tubes (Abbott Labs of Brazil, São Paulo, SP, Brazil) with a 1.0-mm internal diameter, 1.6-mm external diameter, and 10.0-mm length were filled with white MTA (Angelus ${ }^{\circledR}$ ), MTA HP (Angelus ${ }^{\circledR}$ ), and BDT (Septodont ${ }^{\circledR}$ ) prepared according to the manufacturer's instructions. Empty tubes were used as control. The surgical procedure was performed according to previous studies. ${ }^{11,12,14}$ The rats were anesthetized with ketamine $(87 \mathrm{mg} / \mathrm{kg}$ Francotar; Virbac do Brasil Ind e Com Ltda, Roseira, Brazil) and xylazine (13 mg/kg Rompum; Bayer S A, São Paulo, Brazil) administered intramuscularly; their dorsa were shaved, the skin disinfected with 5\% iodine solution, and a $2.0-\mathrm{cm}$ incision was made in a head-to-tail orientation with a \#15 Bard-Parker blade (BD, Franklin Lakes, NJ). The skin was reflected to create two pockets on the right side and two pockets on the left side of the incision. After the tubes were randomly implanted into the pockets and subsequently identified according to the material received, the skin was closed with 4.0 silk sutures.

\section{Systolic blood pressure measurements}

Systolic blood pressure (SBP) was checked in two periods, at preoperative time and before euthanasia, by indirect tail-cuff plethysmography by using Physiograph ${ }^{\circledR}$, MK-III-S (Narco Bio-systems, Houston, Texas, USA), adapted for this purpose. ${ }^{20}$

\section{Histological analysis}

At 7 and 30 days after implantation, animals were euthanized by an overdose of anesthetic; the tubes with surrounding tissue were removed and fixed in $10 \%$ formalin solution $(\mathrm{pH}=7.0)$. The tubes were then 
bisected transversely, and both halves were cut again longitudinally with the use of a sharp blade, allowing the surfaces to be readily kept in contact with the processing solutions. The specimens were processed with glycol methacrylate (GMA). Serial sections 3-mm thick were stained with hematoxylin-eosin, whereas 10-mm sections were processed by von Kossa staining or directly examined under polarized light. ${ }^{11,12}$

Quantitative analysis was performed in all samples or implants: tissue in contact with the material at the tube opening was assessed by counting the average number of inflammatory cells (neutrophils, lymphocytes, plasma cells, and macrophages) and stained with hematoxylin-eosin in 10 randomly selected microscopic fields at 400x magnification by a certified histologist (trained and calibrated) blinded to the experimental condition. ${ }^{11}$ Biomineralization per $\mu \mathrm{m}^{2}$ was determined using Qwin software
(Leica Microsystems, Wetzlar, Germany). After the Shapiro-Wilk test of normality, the Mann-Whitney test was performed for nonparametric data, and a $t$ test was performed for parametric data, using GraphPad Prism 7 software (La Jolla, CA). A p $<0.05$ was considered statistically significant.

\section{Results}

\section{Blood pressure monitoring}

Systolic blood pressure of SHR-7 and SHR-30 was higher $(p<0.05)$ than in NT-7 and NT-30 rats, respectively, at both times of measurement (preoperatively and before euthanasia) (Table 1).

\section{Histological analysis of inflammatory cells}

The average number of inflammatory cells determined at days 7 and 30 is shown in Table 2.

Table 1. Systolic blood pressure \pm SD of normotensive and hypertensive rats.

\begin{tabular}{lcccc}
\hline Systolic blood pressure & \multicolumn{2}{c}{30 days } \\
\hline Groups & Preoperative & Before euthanasia & Preoperative & Before euthanasia \\
Normotensive & $103.4 \pm 2.6$ & $106.2 \pm 2.2$ & $104.7 \pm 2.7$ & $105.1 \pm 2.1$ \\
Hypertensive & $169.2 \pm 3.5^{*}$ & $172.7 \pm 2.9^{*}$ & $170.3 \pm 2.4^{*}$ & $174.1 \pm 3.3^{*}$ \\
\hline
\end{tabular}

${ }^{*} \mathrm{p}<0.05$ between normotensive and hypertensive rats (Student's $t$ test).

Table 2. Means of inflammatory response and biomineralization area under hypertensive and normotensive conditions in the control group, Mineral Trioxide Aggregate (MTA), High-plasticity MTA (MTA HP) and Biodentine ${ }^{\circledR}$ (BDT) at 7 and 30 days.

\begin{tabular}{|c|c|c|c|c|}
\hline \multirow{2}{*}{ Material } & \multicolumn{2}{|c|}{7 days } & \multicolumn{2}{|c|}{30 days } \\
\hline & Normotensive (Mean \pm SD) & Hypertensive (Mean \pm SD) & Normotensive (Mean \pm SD) & Hypertensive (Mean \pm SD) \\
\hline \multicolumn{5}{|c|}{ Inflammatory-H\&E } \\
\hline Control & $304.0 \pm 45.5^{\mathrm{A}}$ & $324.5 \pm 11.2^{\mathrm{A}}$ & $161.3 \pm 73.0^{A}$ & $165.7 \pm 76.2^{A}$ \\
\hline MTA & $233.0 \pm 59.0^{A}$ & $415.3 \pm 167.5^{\mathrm{B}}$ & $169.7 \pm 36.1^{\mathrm{B}}$ & $282.8 \pm 59.4^{B}$ \\
\hline MTA HP & $147.3 \pm 116.6^{A}$ & $352.0 \pm 82.2^{B}$ & $166.6 \pm 92.3^{B}$ & $295.6 \pm 55.8^{8}$ \\
\hline BDT & $207.2 \pm 36.8^{A}$ & $411.8 \pm 50.7^{B}$ & $100.0 \pm 22.8^{B}$ & $297.0 \pm 110.7^{B}$ \\
\hline \multicolumn{5}{|c|}{ Biomineralization-VK } \\
\hline Control & $O^{A}$ & $O^{A}$ & $\mathrm{O}^{\mathrm{A}}$ & $\mathrm{O}^{\mathrm{A}}$ \\
\hline MTA & $73.614 .629 \pm 59.9^{A}$ & $6.245 .385 \pm 51.5^{\mathrm{B}}$ & $103.313 .886 \pm 69.6^{A}$ & $12.260 .179 \pm 13.4^{\mathrm{B}}$ \\
\hline MTA HP & $37.331 .307 \pm 17.5^{\mathrm{A}}$ & $30.793 .842 \pm 3.5^{A}$ & $58.731 .524 \pm 74.7^{A}$ & $46.553 .449 \pm 57.1^{\mathrm{A}}$ \\
\hline BDT & $133.436 .322 \pm 46.3^{\mathrm{A}}$ & $31.826 .145 \pm 17.3^{B}$ & $53.529 .373 \pm 21.3^{A}$ & $17.764 .056 \pm 88.3^{B}$ \\
\hline \multicolumn{5}{|c|}{ Biomineralization-LP } \\
\hline Control & $O^{A}$ & $O^{A}$ & $O^{A}$ & $O^{A}$ \\
\hline MTA & $29.038 .163 \pm 15.9^{\mathrm{A}}$ & $7.972 .073 \pm 17.2^{B}$ & $19.173 .252 \pm 15.1^{\mathrm{A}}$ & $6.200 .072 \pm 7.8^{A}$ \\
\hline MTA HP & $30.807 .951 \pm 16.0^{A}$ & $11.221 .218 \pm 17.0^{\mathrm{B}}$ & $11.203 .325 \pm 14.9^{\mathrm{A}}$ & $7.828 .218 \pm 8.9^{A}$ \\
\hline BDT & $16.450 .616 \pm 91.6^{\mathrm{A}}$ & $5.096 .514 \pm 53.8^{B}$ & $8.535 .598 \pm 8.0^{\mathrm{A}}$ & $3.985 .838 \pm 3.4^{A}$ \\
\hline
\end{tabular}

*Different letters indicate statistically significant differences between normotensive and hypertensive conditions at 7 and 30 days $(p<0.05)$. 
In the control group, there was no statistical difference between NT and hypertensive rats in all periods of analysis ( $p>0.05$ ) (Table 2). MTA, MTA HP, and BDT induced inflammatory response in all periods of analysis. However, a higher number of inflammatory cells was observed in hypertensive rats when compared to NT rats at 7 days $(\mathrm{p}<0.05)$ (Table 2). Macrophages and lymphocytes were the predominant cell types detected in the tissue (Figure 1).

\section{Histological analysis of biomineralization}

The analysis using von Kossa staining revealed the presence of positive calcifications in all materials and in all periods of analysis (Table 2, Figure 2). On the other hand, positive calcifications were not present in control groups. In the MTA and BDT groups, a greater area of biomineralization was found in NT rats when compared to hypertensive ones in all periods of analysis $(\mathrm{p}<0.05)$ (Table 2$)$. In the MTA HP group, a similar area of positive calcifications was observed in NT rats when compared to hypertensive ones in all periods of analysis ( $p>0.05$ ) (Table 2).

The analysis of birefringence under polarized light revealed the presence of calcifications in all materials in all periods of analysis (Table 2, Figure 3). In the control group, there was no presence of calcifications. At 7 days, a greater area of calcifications was found in NT rats when compared to hypertensive ones

NT 7D

SHR 7D

NT 30D

SHR 30D
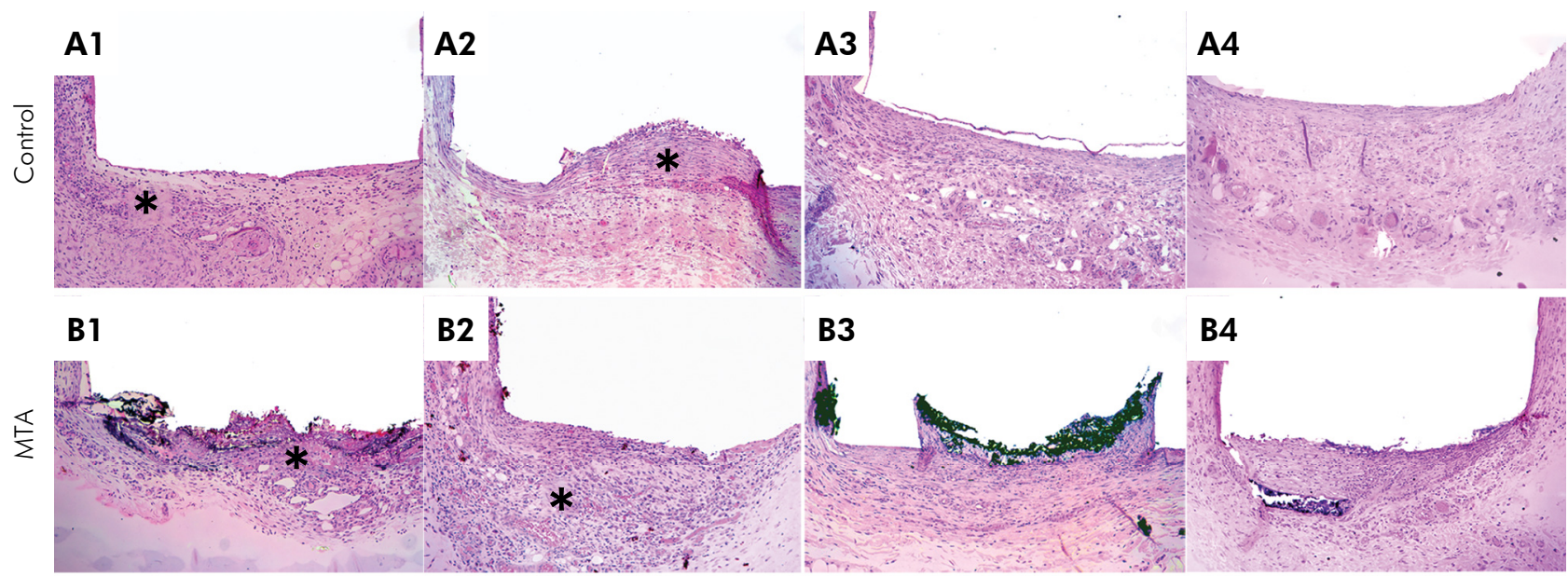

B3

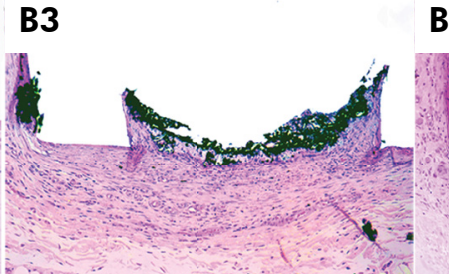

B4

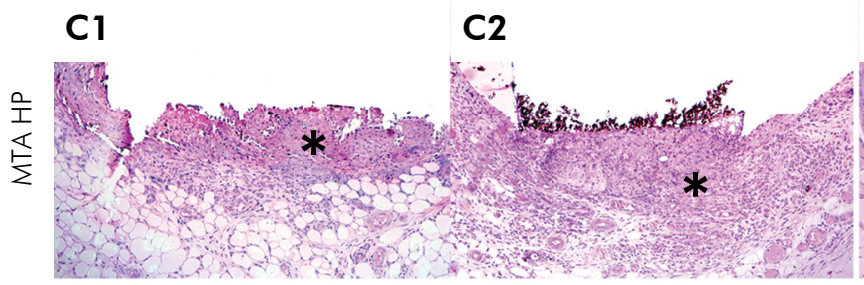

C3

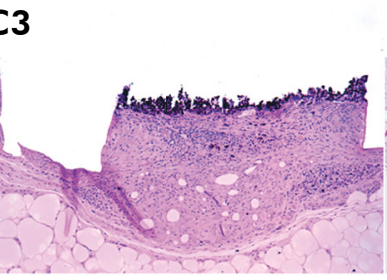

C4

D1

D2

D3

D4

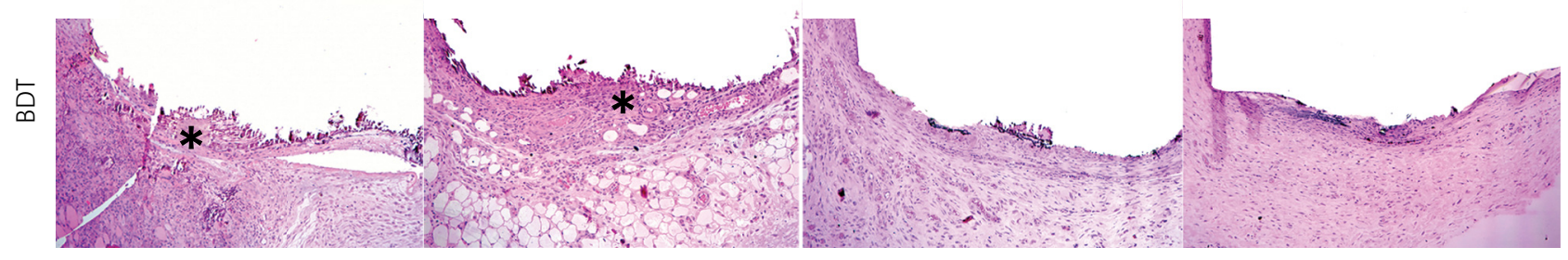

Figure 1. Representative images of inflammatory reaction in normotensive/hypertensive condition (NT/SHR), stained with hematoxylin-eosin. Fibrous capsule with greater density of inflammatory infiltrate (asterisk) (macrophages and lymphocytes) in the presence of MTA, MTA HP, and BDT under hypertensive conditions at 7 and 30 days (Scale bars: $200 \mu$ m; Original magnification: $100 \times)$. ${ }^{*}$ Mineral Trioxide Aggregate (MTA), High-plasticity MTA (MTA HP), and Biodentine ${ }^{\circledR}$ (BDT). 
NT 7D
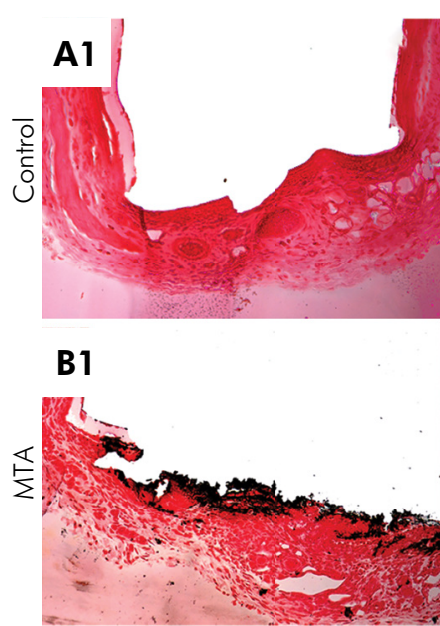

C1

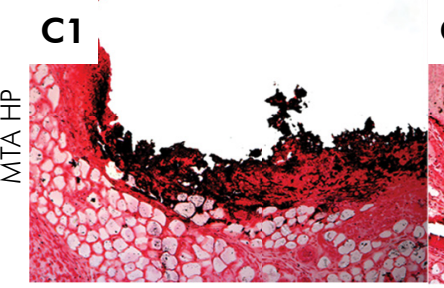

SHR 7D

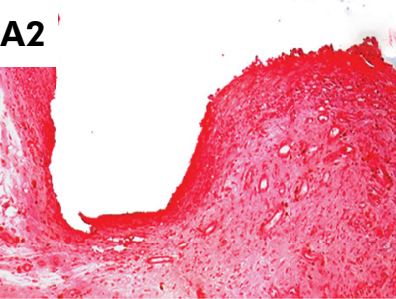

B2

D1

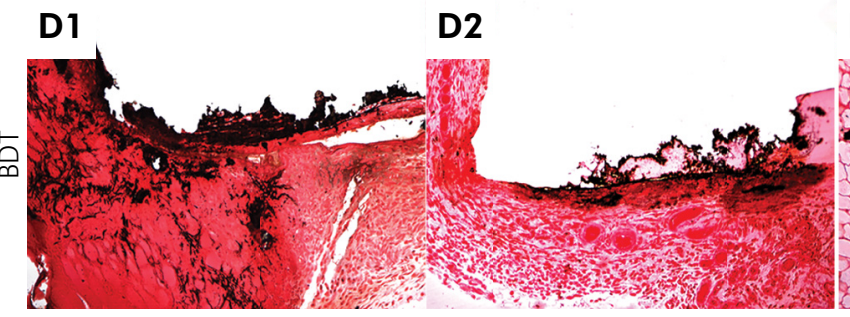

NT 30D
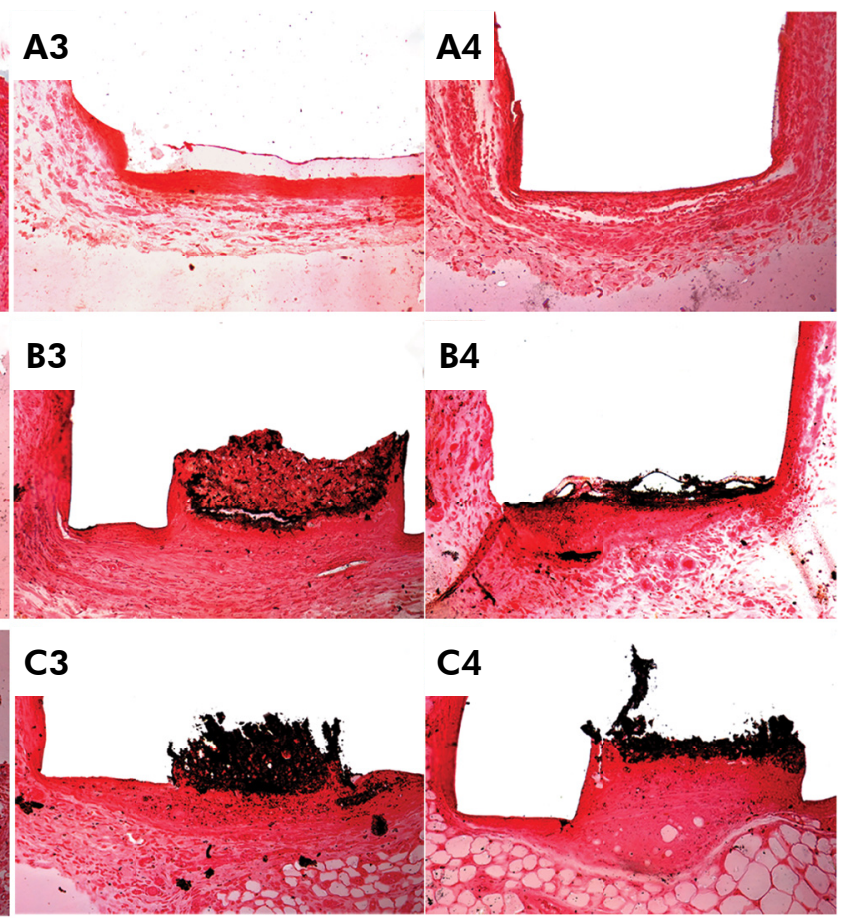

D3

Figure 2. Representative images of biomineralization determined by von Kossa staining under normotensive/hypertensive conditions (NT/SHR). The black areas represent presence of calcifications. MTA, MTA HP, and BDT induced biomineralization, which was not observed in the control group. MTA HP induces similar mineralization under normotensive/hypertensive conditions in both periods of analysis. More consistent biomineralization was observed in MTA and BDT under normotensive condition at 7 and 30 days (Scale bars: $200 \mu \mathrm{m}$; Original magnification: 100×). ${ }^{*}$ Mineral Trioxide Aggregate (MTA), High-plasticity MTA (MTA HP), and Biodentine ${ }^{\circledR}(B D T)$.

in all materials $(\mathrm{p}<0.05)$ (Table 2$)$. At 30 days, a similar area of calcifications was observed in all materials, regardless of the hypersensitive condition $(\mathrm{p}>0.05)$ (Table 2).

\section{Discussion}

The present study shows that HTN is able to increase tissue inflammation and decrease the biomineralization capacity of calcium silicate-based repair cements. To the authors' knowledge, only one study has shown that HTN alters the biocompatibility and biomineralization of MTA. ${ }^{11}$ Therefore, this is the first study to show that tissue reaction and biomineralization are negatively affected by HTN in $\mathrm{BDT}^{\circledR}$ and MTA HP.

The SHR model was used because its pathophysiology is similar to that of hypertension in humans. ${ }^{21}$ SHR were developed by genetic endogamy (brother-to-sister), resulting in 100\% natural hypertensive disease, thus developing hypertension without physiological, pharmacological, or surgical intervention. ${ }^{21}$ These animals are born normotensive with mean arterial pressure around $112 \mathrm{mmHg}$ and 


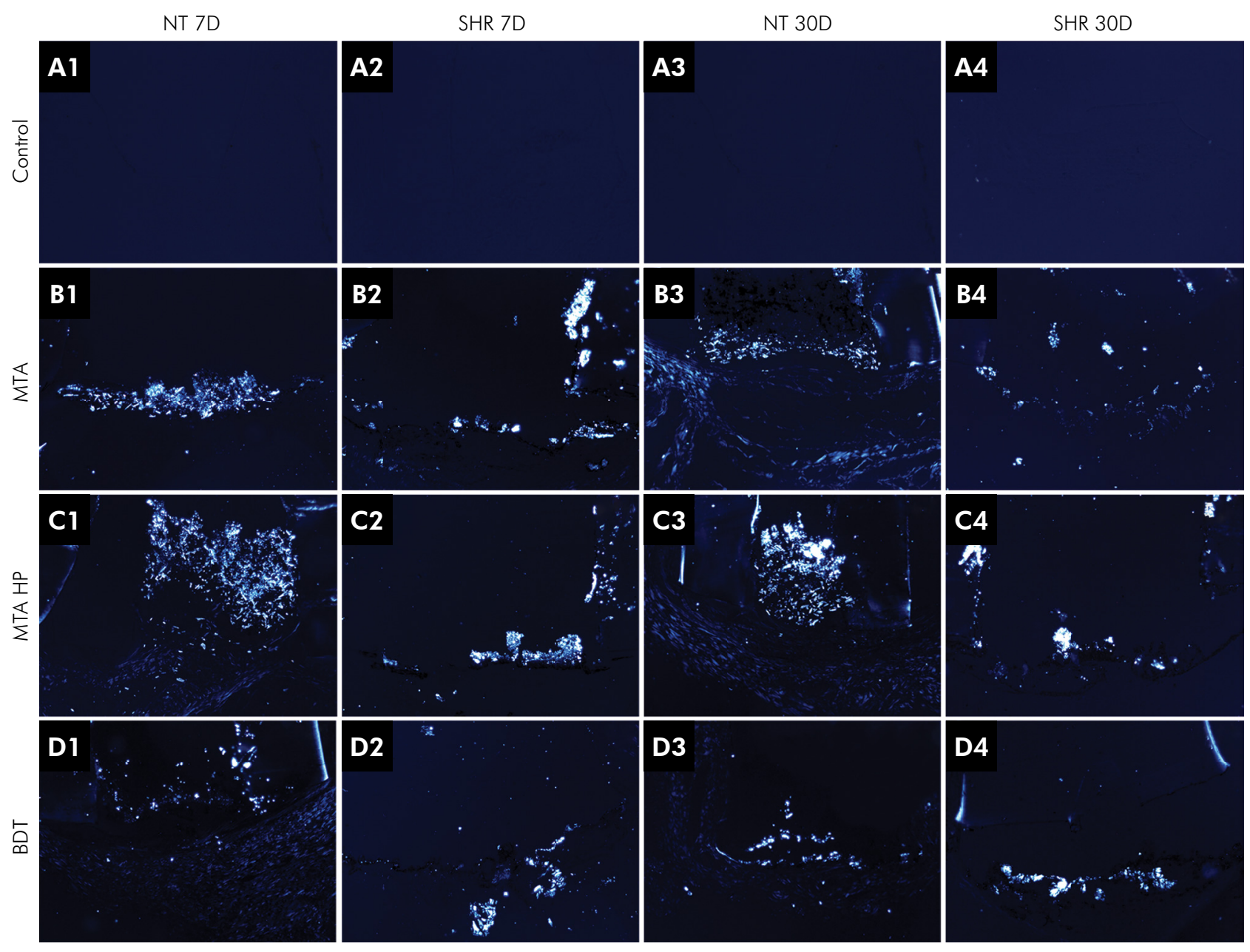

Figure 3. Representative images of biomineralization determined by polarized light microscopy under normotensive/hypertensive conditions (NT/SHR). Birefringent structures in the tissue represent presence of calcifications. MTA, MTA HP, and BDT induced biomineralization, which was not observed in the control group. More consistent biomineralization was observed in MTA, MTA HP, and BDT under normotensive conditions, especially at 7 days (Scale bars: $200 \mu \mathrm{m}$; Original magnification: 100×). ${ }^{*}$ Mineral Trioxide Aggregate (MTA), High-plasticity MTA (MTA HP), and Biodentine ${ }^{\circledR}$ (BDT).

spontaneously develop hypertension, reaching values higher than $150 \mathrm{mmHg}$ at 3 months of life; male SHR have markedly higher diastolic and systolic blood pressure compared to female SHR. ${ }^{22,23}$ Due to sex characteristics and the time of development of blood pressure, SHR males aged 3 months of life were used in this study. Subcutaneous implantation was used to analyze biocompatibility, as it is an appropriate model for evaluating the response of the potential biomaterials in the tissue. ${ }^{12,13,14,24}$ The dispersion area of the material in the subcutaneous tissue is delimited by the polyethylene tube, which is useful for evaluating the local effects of biomaterials on the area of interest, following International
Standard ISO $10993-6 .{ }^{25}$ In addition, it is a method for preliminary in vivo evaluation of tissue response induced by the materials. ${ }^{25}$

Biocompatible materials are not inert, but should not cause an intense physiological response in the host. Mineral Trioxide Aggregate, High-plasticity MTA, and Biodentine ${ }^{\circledR}$ remain in contact with pulp tissue and/or periapical tissue when clinically applied. Therefore, these materials must be biocompatible and induce the development of a mineralized tissue that can protect vital tissues and also assist in the repair process of the region. ${ }^{14}$

The present study showed that inflammatory response was more exacerbated in MTA, MTA HP, and 
BDT when implanted in SHR. This is consistent with another study that shows that calcium silicate-based cement inflammation increases in the presence of HTN. ${ }^{11}$ Host response to substances released by materials is the main factor that influences progression and the type of inflammatory infiltrate. Immune cells release cytokines and growth factors that play a key role in the inflammatory process. ${ }^{26}$ However, tissue response to cement may be altered in HTN because of increased proliferation and infiltration of lymphocytes and also because of increased plasma concentrations of proinflammatory cytokines such as interleukin-6 (IL-6), interleukin-1 beta (IL-1 $\beta$ ), and tumor necrosis factor alpha (TNF- $\alpha$ ), stimulated by the high level of angiotensin II and up-regulation of C-reactive protein..$^{10}$

The lower mineralization quality presented by the materials in the hypertensive groups could be related to the ability of HTN to affect mineralized tissues due to the increased serum levels of parathyroid hormone. This hormone leads to the activation of vitamin D, which is responsible for stimulating the breakdown of bone through the activation and proliferation of osteoclasts, increasing blood calcium levels and calcium excretion by the kidneys. Furthermore, angiotensin II up-regulates RANKL expression, which binds to RANK, a receptor present on the surface of osteoclast precursors, initiating osteoclast differentiation and activation, resulting in more osteoclasts than osteoblasts. These conditions lead to increased mineral loss, suggesting a negative association among high blood pressure and bone mineral density, bone modeling, and mineralization. $27,28,29,30$

The materials used in this study are based on calcium silicate but with some specific characteristics: MTA is composed of course particles, hence the "sandy" feel. ${ }^{31}$ Due to the physical properties inherent to the MTA powder, the sandy consistency hinders manipulation and transport of the material to the site of repair. To improve these characteristics, MTA HP was developed, and according to the manufacturer, the result is a product with greater plasticity, facilitating manipulation and insertion in the dental cavity. ${ }^{31}$ In BDT, the water base, supplied in ampoules, contains a "plasticizer" (polycarboxylate) and calcium chloride to enhance the properties and speed up the setting; ${ }^{32}$ its fine powder and faster setting are improvements over the original MTA. ${ }^{33}$ When these materials come into contact with tissue, they release calcium and hydroxyl ions, and these ions form calcium hydroxide, increasing $\mathrm{pH}$ and consequently triggering an inflammatory response. ${ }^{34,35}$ These ions react with the carbon dioxide present in the tissue, originating calcified structures (amorphous form of calcium phosphate and/or carbonate apatite) that are related to the decrease of inflammation and are also related to the process of tissue biomineralization, which promotes repair. ${ }^{11,12,14,24,34,35,36}$

In the present study, biomineralization was evaluated by the von Kossa method and by the presence of birefringent structures under polarized light, which detects production of $\mathrm{Ca}$ and $\mathrm{P}$ surface precipitates and a Ca- and P-rich layer at the interface between material and tissue. ${ }^{37}$ Polarized light microscopy, a variation of standard light microscopy, is frequently used to help identify crystalline materials in histological sections without using exogenous dyes or labels. ${ }^{37}$ The von Kossa technique is a histological staining method that is frequently used to identify calcified structures. ${ }^{11,12,14,24}$ Viola et al. ${ }^{24}$ compared von Kossa staining in the tibiae of non-decalcified rats with biomaterial-induced marking the basis of calcium silicate in the subcutaneous tissue of rats. The authors concluded that calcified structures marked in the subcutaneous tissue were similar to those marked in the tibia, suggesting that calcium silicate-based biomaterials are able to induce the deposition of calcified structures. ${ }^{24}$ Moreover, positive von Kossa labeling and birefringence under polarized light of rat connective tissues show that these biomaterials have osteoinductive potential. ${ }^{24,35}$

Hypertension negatively influenced the deposition of calcified components in MTA and BDT, compromising their biomineralization ability. In the MTA HP group, similar deposition of calcified components was observed in the NT group in both periods of analysis. Birefringent calcified components were less present in HTN after 7 days in the MTA, MTA HP, and BDT groups, suggesting that the initial phase of biomineralization was compromised in HTN. However, further immunohistochemical studies for 
analysis of mineralization and inflammation markers could be conducted.

These materials have to be tested before being launched in the market and applied in the global community presenting the most varied systemic disorders. Our research group is centered on biological investigations and this is the first study on these materials under hypertensive conditions. As in any preclinical experimental research, the outcomes of this study should be viewed with caution because of some methodological limitations. The use of animals enables us to examine these materials under remarkably controlled laboratory conditions prior to their use in humans; however, it does not portray precisely the conditions manifested by humans. Moreover, although SHR is the closest experimental animal model to human hypertension, the results should be taken into consideration the expectations in humans, since hypertension alters the biocompatibility and biomineralization of repair materials.

\section{Conclusion}

HTN was able to increase inflammatory infiltrate and decrease the biomineralization of MTA, MTA $\mathrm{HP}$, and BDT.

\section{Acknowledgments}

The authors thank Prof Sandra Helena Penha de Oliveira - Department of Basic Science, São Paulo State University (Unesp), School of Dentistry (Araçatuba-SP) for the donation of spontaneously hypertensive rats, and Programa Institucional de Bolsas de Iniciação Científica e Tecnologica (PIBIC/CNpQ 41787) for the scholarship granted.

\section{References}

1. World Health Organization - WHO. A global brief on hypertension. Geneva: World Health Organization; 2013 [cited 2016 Mar 30]. Available from: http://www.who.int/cardiovascular_diseases/publications/global_brief hypertension/en/

2. Whelton PK, Carey RM, Aronow WS, Casey DE Jr, Collins KJ, Dennison Himmelfarb C, et al. 2017 ACC/AHA/AAPA/ABC/ACPM/ AGS/APhA/ASH/ASPC/NMA/PCNA Guideline for the prevention, detection, evaluation, and management of high blood pressure in adults: executive summary: a report of the American College of Cardiology/American Heart Association Task Force on Clinical Practice Guidelines. Hypertension. 2018 Jun;71(6):1269-324. https://doi.org/10.1161/HYP.0000000000000066

3. Oparil S, Acelajado MC, Bakris GL, Berlowitz DR, Cifkova R, Dominiczak AF, et al. Hypertension. Nat Rev Dis Primers. 2018;(4):1-21.

4. Poulter NR, Prabhakaran D, Caulfield M. Hypertension. Lancet. 2015 Aug;386(9995):801-12. https://doi.org/10.1016/S0140-6736(14)61468-9

5. Mills KT, Bundy JD, Kelly TN, Reed JE, Kearney PM, Reynolds K, et al. Global Disparities of Hypertension Prevalence and Control: A Systematic Analysis of Population-Based Studies From 90 Countries. Circulation. 2016 Aug;134(6):441-50. https://doi.org/10.1161/CIRCULATIONAHA.115.018912

6. Forouzanfar MH, Liu P, Roth GA, Ng M, Biryukov S, Marczak L, et al. Global Burden of Hypertension and Systolic Blood Pressure of at Least 110 to 115 mm Hg, 1990-2015. JAMA. 2017 Jan;317(2):165-82. https://doi.org/10.1001/jama.2016.19043

7. Gadallah M, Massry SG, Bigazzi R, Horst RL, Eggena P, Campese VM. Intestinal absorption of calcium and calcium metabolism in patients with essential hypertension and normal renal function. Am J Hypertens. 1991 May;4(5 Pf 1):404-9. https://doi.org/10.1093/ajh/4.5.404

8. Panoulas VF, Metsios GS, Pace AV, John H, Treharne GJ, Banks MJ, et al. Hypertension in rheumatoid arthritis. Rheumatology (Oxford). 2008 Sep;47(9):1286-98. https://doi.org/10.1093/rheumatology/ken159

9. Tokutomi F, Wada-Takahashi S, Sugiyama S, Toyama T, Sato T, Hamada N, et al. Porphyromonas gingivalis-induced alveolar bone loss is accelerated in the stroke-prone spontaneously hypertensive rat. Arch Oral Biol. 2015 Jun;60(6):911-8. https://doi.org/10.1016/i.archoralbio.2015.02.012

10. Dinh QN, Drummond GR, Sobey CG, Chrissobolis S. Roles of inflammation, oxidative stress, and vascular dysfunction in hypertension. BioMed Res Int. 2014;2014(1):406960. https://doi.org/10.1155/2014/406960

11. Martins CM, Gomes-Filho JE, de Azevedo Queiroz IO, Ervolino E, Cintra LT. Hypertension Undermines Mineralization-inducing Capacity of and Tissue Response to Mineral Trioxide Aggregate Endodontic Cement. J Endod. 2016 Apr;42(4):604-9. https://doi.org/10.1016/i.joen.2016.01.003 
12. Gomes-Filho JE, Rodrigues G, Watanabe S, Estrada Bernabé PF, Lodi CS, Gomes AC, et al. Evaluation of the tissue reaction to fast endodontic cement (CER) and Angelus MTA. J Endod. 2009 Oct;35(10):1377-80. https://doi.org/10.1016/j.joen.2009.06.010

13. Cosme-Silva L, Gomes-Filho JE, Benetti F, Dal-Fabbro R, Sakai VT, Cintra LTA, et al. Biocompatibility and immunohistochemical evaluation of a new calcium silicate-based cement, Bio-C Pulpo. Int Endod J. 2019 May;52(5):689-700. https://doi.org/10.1111/iej.13052

14. Cintra LT, Benetti F, Queiroz IOA, Lopes JMA, Oliveira SHP, Araújo GS, et al. Cytotoxicity, Biocompatibility, and Biomineralization of the New High-plasticity MTA Material. J Endod. 2017 May;43(5):774-8. https://doi.org/10.1016/i.joen.2016.12.018

15. Araújo LB, Cosme-Silva L, Fernandes AP, Oliveira TM, Cavalcanti BD, Gomes Filho JE, et al. Effects of mineral trioxide aggregate, BiodentineTM and calcium hydroxide on viability, proliferation, migration and differentiation of stem cells from human exfoliated deciduous teeth. J Appl Oral Sci. 2018 Feb;26(0):e20160629. https://doi.org/10.1590/1678-7757-2016-0629

16. Alsulaimani RS. Immediate and delayed repair of 2 sizes of furcal perforations in dogs' teeth using mineral trioxide aggregate cement. J Endod. 2018 Jun;44(6):1000-6. https://doi.org/10.1016/i.joen.2018.02.026

17. Cosme-Silva L, Carnevalli B, Sakai VT, Viola NV, Carvalho LF, Carvalho EMF. Radicular perforation repair with mineral trioxide aggregate: a case report with 10-year follow-up. Open Dent J. 2016 Dec;10(1):733-8. https://doi.org/10.2174/1874210601610010733

18. Junqueira MA, Cunha NN, Caixeta FF, Marques NC, Oliveira TM, Moretti AB, et al. Clinical, Radiographic and Histological Evaluation of Primary Teeth Pulpotomy Using MTA And Ferric Sulfate. Braz Dent J. 2018 Mar-Apr;29(2):159-65. https://doi.org/10.1590/0103-6440201801659

19. Katge FA, Patil DP. Comparative analysis of 2 calcium silicate-based cements (biodentine and mineral trioxide aggregate) as direct pulp-capping agent in young permanent molars: a split mouth study. J Endod. 2017 Apr;43(4):507-13. https://doi.org/10.1016/j.joen.2016.11.026

20. Manrique N, Pereira CC, Garcia LM, Micaroni S, Carvalho AA, Perri SH, et al. Alveolar bone healing process in spontaneously hypertensive rats (SHR). A radiographic densitometry study. J Appl Oral Sci. 2012 Mar-Apr;20(2):222-7. https://doi.org/10.1590/S1678-77572012000200017

21. Okamoto, Aoki K. Development of a strain of spontaneously hypertensive rats. Jpn Circ J. 1963 Mar;27:282-93.

22. Horvathova M, Zitnanova I, Kralovicova Z, Balis P, Puzserova A, Muchova J, et al. Sex differences in the blood antioxidant defense system in juvenile rats with various genetic predispositions to hypertension. Hypertens Res. 2016 Feb;39(2):64-9. https://doi.org/10.1038/hr.2015.117

23. Swales JD. Textbook of hypertension. Oxford: Blackwell Scientific; 1994.

24. Viola NV, Guerreiro-Tanomaru JM, Silva GF, Sasso-Cerri E, Tanomaru-Filho M, Cerri PS. Biocompatibility of an experimental MTA sealer implanted in the rat subcutaneous: quantitative and immunohistochemical evaluation. J Biomed Mater Res B Appl Biomater. 2012 Oct;100(7):1773-81. https://doi.org/10.1002/ibm.b.32744

25. International Organization for Standardization - ISO. ISO 10993-6 Biological evaluation of medical devices. Part 6: Tests for local effects after implantation. Geneve: International Organization for Standardization; 2016 [cited 2018 Nov 12]. Available from: https://www.iso.org/standard/61089.html

26. Franz S, Rammelt S, Scharnweber D, Simon JC. Immune responses to implants - a review of the implications for the design of immunomodulatory biomaterials. Biomaterials. 2011 Oct;32(28):6692-709. https://doi.org/10.1016/i.biomaterials.2011.05.078

27. MacGregor GA, Cappuccio FP. The kidney and essential hypertension: a link to osteoporosis? J Hypertens. 1993 Aug;11(8):781-5. https://doi.org/10.1097/00004872-199308000-00003

28. Wang TM, Hsu JF, Jee WS, Matthews JL. Evidence for reduced cancellous bone mass in the spontaneously hypertensive rat. Bone Miner. 1993 Mar;20(3):251-64. https://doi.org/10.1016/S0169-6009(08)80006-2

29. Shimizu H, Nakagami H, Osako MK, Hanayama R, Kunugiza Y, Kizawa T, et al. Angiotensin Il accelerates osteoporosis by activating osteoclasts. FASEB J. 2008 Jul;22(7):2465-75. https://doi.org/10.1096/fi.07-098954

30. Shen Y, Jiang T, Wang R, He S, Guo M, Zuo J, et al. (5R)-5-Hydroxytriptolide (LLDT-8) inhibits osteoclastogenesis via RANKL/RANK/ OPG signaling pathway. BMC Complement Altern Med. 2015 Mar;15(1):77. https://doi.org/10.1186/s12906-015-0566-y

31. Angelus ${ }^{\circledR}$ Indústria de Produtos Odontológicos S/A. MTA REPAIR HP 2018. Londrina: Angelus; 2018 [cited 2018 Oct 14]. Available from: http://angelus.ind.br/MTA-REPAIR-HP-292.html

32. Camilleri J, Montesin FE, Di Silvio L, Pitt Ford TR. The chemical constitution and biocompatibility of accelerated Portland cement for endodontic use. Int Endod J. 2005 Nov;38(11):834-42. https://doi.org/10.1111/j.1365-2591.2005.01028.x

33. Camilleri J, editor. Mineral trioxide aggregate in dentistry: from preparation to application. New York: Springer; 2014.

34. Camilleri J. Characterization of hydration products of mineral trioxide aggregate. Int Endod J. 2008 May;41(5):408-17. https://doi.org/10.1111/j.1365-2591.2007.01370.x

35. Holland R, de Souza V, Nery MJ, Otoboni Filho JA, Bernabé PF, Dezan Júnior E. Reaction of rat connective tissue to implanted dentin tubes filled with mineral trioxide aggregate or calcium hydroxide. J Endod. 1999 Mar;25(3):161-6. https://doi.org/10.1016/S0099-2399(99)80134-4 
Hypertension affects the biocompatibility and biomineralization of MTA, High-plasticity MTA, and Biodentine ${ }^{\circledast}$

36. Bueno CRE, Vasques AMV, Cury MTS, Sivieri-Araujo G, Jacinto RC, Gomes-Filho JE, et al. Biocompatibility and biomineralization assessment of mineral trioxide aggregate flow. Clin Oral Investig. 2019 Jan;23(1):169-177. https://doi.org/10.1007/s00784-018-2423-0.

37. Clineff TD, Erbe EM, Baver TW, Carroll BE. Analytical technique for quantification of selected resorbable calcium phosphate bone void fillers with the use of polarized-light microscopy. J Biomed Mater Res B Appl Biomater. 2005 Jan;72(1):125-30. https://doi.org/10.1002/jbm.b.30124 